\title{
HAK NAFKAH BAGI ISTERI YANG MENGGUGAT CERAI \\ DENGAN ALASAN KEKERASAN DALAM RUMAH TANGGA
}

\author{
Salma \\ Fakultas Syariah, Institut Agama Islam Negeri Manado, Indonesia \\ Email: salmaiain@yahoo.co.id \\ Nadila Awad \\ Fakultas Syariah, Institut Agama Islam Negeri Manado, Indonesia \\ Email: nadilaawad11@gmail.com
}

\begin{abstract}
ABSTRAK
Pernikahan merupakan hal sakral yang diperintahkan oleh Allah Swt. sebagai penyempurna iman, namun dalam perjalanannya terkadang keegoisan dan sifat asli dari pasangan membuat keretakan dalam menjalaninya, kadang rasa marah terluapkan dengan kekerasan, bahkan penganiayaan, dan sering kali wanita yang menjadi korban. Tulisan ini menggunakan metode penelitian kepustakaan (library research) yang diambil dari berbagai penelitian ilmiah. Adapun hasil dari tulisan ini dapat dideskripsikan bahwa dalam Islam, jika perempuan tidak menaati perintah suami, maka perceraian tersebut dinamakan dengan khulu' dan harus memberikan iwadl kepada suami sebagai kesepakatan untuk mau bercerai, namun hukum di Indonesia mengatur tentang seorang isteri yang menggugat cerai suami dikarenakan kekerasan dalam rumah tangga yang terjadi secara terus-menerus yang sukar untuk disembuhkan kemudian menggugat nafkah iddah, mut'ah dan madhiyyah, sedangkan dia tidak nusyuz kepada suaminya, maka hakim berhak memeriksa dan mengadili perkara tersebut untuk mendapatkan kemaslahatan dari kedua pihak yang berperkara.
\end{abstract}

Kata kunci: Hak Nafkah; Perceraian; Kekerasan dalam Rumah Tangga. 


\section{PENDAHULUAN}

Pernikahan merupakan ibadah yang dilaksanakan tanpa putus, setelah akad nikah dilaksanakan, maka apa yang dilakukan suami isteri terhitung Ibadah, mendapatkan jodoh terbaik adalah hal yang diidam-idamkan oleh semua orang, pernikahan yang dilandasi rasa cinta satu sama lain dengan cita cita bisa sehidup semati, dipertemukan kembali di surganya Allah Swt., mendapatkan keturunan yang sholeh sholehah, siapa yang tidak mau bernasip demikian. Namun realita yang tidak sesuai ekspektasi pasti selalu ada saja, mulai dari terkuaknya sifat asli pasangan yang ternyata tidak sebaik masa sebelum menikah, ekonomi yang tidak berkecukupan, tidak saling pengertian antara suami dan Isteri, dan lain-lain. Tidak jarang amarah yang dikeluarkan pasangan menjadi tidak terkendalikan dan terluapkan dalam kekerasan fisik menjadi salah satu masalah yang timbul dalam dunia pernikahan, hal ini biasanya terjadi pada kaum wanita sebagai korban, dikarenakan selalu dianggap sebagai mahluk yang lemah.

Pernikahan yang terdiri dari dua orang yang memiliki egoisme masingmasing, maka tidak mungkin kapal rumah tangga itu dapat berjalan tanpa melewati ombak, mulai dari guncangan yang kecil sampai guncangan besar pasti akan dihadapi pasangan suami isteri. Ego yang sudah ada dalam fitrah kehidupan diri manusia tidak terlepas dari keinginan untuk memenuhi kebutuhan yang diinginkan diri, termasuk didalamnya kebutuhan biologis berupa seksualitas, maka dengan cara pernikahanlah manusia dapat memenuhi kebutuhan seksualnya secara halal lagi baik. Di samping itu, pernikahan seharusnya dijalani dengan tujuan sakinah atau ketentraman bagi semua orang yang menjalaninya, namun seringkali ada kalanya seseorang khilaf dan melakukan kekerasan dalam rumah tangga.

Kepahaman tentang kekerasan dalam rumah tangga sering kali hanya seputar kekerasan fisik, padahal bukan hanya seputar kekerasan fisik saja yang merupakan kekerasan dalam rumah tangga, hal ini sebagaimana dituliskan dalam Undang-Undang (UU) Tentang Penghapusan Kekerasan Dalam Rumah Tangga, (2004), pasal 1 bahwa kekerasan dalam rumah tangga adalah setiap perbuatan terhadap seseorang terutama perempuan, yang berakibat timbulnya kesengsaraan atau penderitaan secara fisik, seksual, psikologis, dan penelantaran rumah tangga. Hal tersebut jika terjadi dalam rumah tangga maka mempunyai kekuatan hukum dan dapat ditindak lanjuti. Kekerasan dalam rumah tangga menurut hukum Islam termasuk dalam kejahatan terhadap nyawa dan mengancam orang lain, dan disebut sebagai al-jarh (Kadarisman, 2017).

Para isteri yang menjadi korban kekerasan dalam rumah tangga banyak yang tidak berani menggugat cerai suaminya dikarenakan sering diancam bahkan 
menggunakan kekerasan dalam pengancamannya, ataupun banyak kasus diantaranya karena isteri tidak memiliki pekerjaan atau keluarga lain untuk bertahan hidup setidaknya sampai mental yang telah dihancurkan dapat sedikit membaik. Jika dalam agama Islam kita mengenal perceraian khulu' yang mewajibkan isteri membayar iwadh kepada suami jika menggugat cerai, namun ternyata Indonesia mengatur hak-hak yang didapatkan isteri jika menggugat cerai, hak tersebut berupa nafkah yang bisa diperoleh setelah bercerai. Tulisan ini akan mengkaji lebih dalam mengenai hal tersebut.

\section{METODE PENELITIAN}

Bahan yang digunakan dalam penulisan ini adalah ketentuan tentang pernikahan, kekerasan dalam rumah tangga, perceraian, serta hak nafkah bagi istri setelah bercerai, sesuai dengan hukum Islam dan peraturan di Indonesia. Adapun metode yang digunakan dalam tulisan ini menggunakan metode penelitian kepustakaan (library research). Sebagai upaya untuk melengkapi isi dari tulisan ini, penulis mendapatkan data dari jurnal ilmiah, serta karya ilmiah lainnya yang bersangkutan dengan tulisan.

\section{HASIL DAN PEMBAHASAN}

\section{Pernikahan, Kekerasan dalam Rumah Tangga dan Perceraian}

Pernikahan adalah sunnah Rasulullah saw., agama Islam sudah mengatur segalanya dalam ruang lingkup pernikahan, mulai dari doa meminta jodoh yang dapat menuntun sebagai imam dalam rumah tangga, sampai keseharian sebagai seuami isteri, dengan impian dapat bersama-sama masuk dan bertemu di surganya Allah Swt.

Faktor faktor terjadinya kekerasan dalam rumah tangga, tergolong menjadi dua bagian, yaitu faktor eksternal yang bukan datang dari sifat awal pelaku, misalnya pelaku melakukan kekerasan dalam rumah tangga dikarenakan faktor ekonomi dan stres yang berlebihan disebabkan oleh tekanan dari lingkungan dan faktor internal yang berasal dari sifat dari pelaku kekerasan dalam rumah tangga, sifat ini dapat berupa mudah marah pada hal-hal kecil dan cenderung main tangan kepada orang sekitar (Mardiyati, 2015).

Korban kekerasan dalam rumah tangga juga terjadi pada anak, bentuk kekerasan yang dialami anak, yaitu kekerasan fisik, psikis dan sosial, hal ini menyebabkan anak mengalami kesakitan fisik seperti memar, luka, benjolan, dll, dampak lainya adalah anak menjadi malu bertemu dengan orang lain, tidak mau bertemu dengan orang lain, dan anak tidak mendapatkan kasih sayang yang seharusnya dia dapatkan dari orang tuanya (Anggraeni, 2013). 
Seorang isteri yang mendapatkan prelakuan kekerasan dalam rumah tangga dapat melaporkan kepada pihak berwenang tentang hal yang dialaminya, namun hal ini sering dianggap tabu, dikarenakan wanita yang sudah dinikahi dianggap harus menaati apapun perintah dan perlakuan suami padanya, padahal setiap orang yang hidup memiliki hak asasi manusia yang sudah ada sejak dia lahir, di Indonesia kekerasan dalam rumah tangga sudah diatur dalam Undangundang, dan ada sanksi yang akan diperoleh, namun ternyata kesadaran korban terutama perempuan atas hal ini terus meningkat hal ini dapat dilihat berdasarkan data cerai gugat semakin meningkat dibandingkan dengan cerai talak (Rofiah, 2017).

Sudut pandang Islam menjelaskan bahwa perceraian tidak termasuk dalam hal yang dilarang oleh agama, namun perceraian dianggap sebagai pilihan terakhir yang dapat dipilih jika tidak mendapatkan jalan keluar lain dari kehidupan pernikahan, di Indonesia perceraian untuk orang yang beragama Islam diatur tentang perceraian hanya dapat dilakukan di depan sidang pengadilan dan bukan dengan putusan pengadilan, dikarenakan perceraian merupakan perkara talak dalam agama Islam (Azizah, 2012). Terdapat perbedaan dari perceraian sesuai dengan agama Islam, dan ketentuan undang-undang, salah satunya adalah jika perceraian dalam Islam dapat dilakukan dimana saja oleh suami atau ketika suami menjatuhkan talak boleh dimana saja, namun menurut peraturan yang ada di Indonesia, taklik talah hanya boleh dilakukan pada saat sidang di Pengadilan Agama.

Perceraian di Indonesia dibagi menjadi dua jenis yakni perceraian talak dan perceraian gugat. Cerai talak merupakan cerai yang diajukan suami kepada Isteri ke Pengadilan Agama, sedangkan cerai gugat adalah kebalikannya yakni isteri yang menggugat cerai suami ke Pengadilan. Dalam Islam, gugatan cerai isteri ke suami adalah perkara khulu' yakni bermakna keinginan untuk suami melepaskan isterinya dari status pernikahan. Khulu' menurut para Ulama', khulu' adalah perpisahan antara suami isteri dengan keikhlasan dari kedua belah pihak dan isteri harus membayarkan iwadh kepada suaminya. Khulu' terjadi dikarenakan beberapa alasan, yaitu:

1) Dalam perkawinan ada pihak yang melakukan perbuatan yang susah disembuhkan seperti zina, mabuk-mabukan, berjudi dan lain-lain;

2) Meninggalkan isteri selama dua tahun berturut-turut dan tanpa meminta atau diberikan izin dari pihak lainnya;

3) Suami mendapatkan hukuman penjara selama lima tahun atau lebih setelah dilangsungkannya akad nikah; 
4) Suami melakukan hal-hal yang dapat menjadi ancaman yang membahayakan seperti menganiaya dan kekerasan;

5) Mendapatkan penyakit yang menjadi alasan tidak dapat memenuhi kewajiban sebagai pasangan suami isteri;

6) Perselisihan dan pertengkaran yang terus menerus terjadi;

7) Suami melanggar taklik talak, dan;

8) Suami meninggalkan agama Islam atau murtad.

Penjabaran alasan-alasan terjadinya khulu' di atas dapat dilihat bahwa penganiayaan dan kekejaman juga termasuk di dalamnya, maka cerai khulu' bisa menjadi internatif untuk isteri yang mengalami kekerasan dalam rumah tangga untuk lepas dari suaminya. Proses pelaksanaan khulu' diatur dalam KHI pasal 148, yaitu sebagai berikut:

1) Penyampaian keinginan untuk khulu' oleh isteri ke Pengadilan agama sesuai dengan tempat tinggalnya dan menyampaikan alasan pengajuannya;

2) Pengadilan agama akan melakukan panggilan untuk suami dan isteri selambatnya tiga puluh hari;

3) Diberikan penjelasan tentang akibat yang akan ditimbulkan dari khulu' oleh pengadilan Agama, tidak lupa diberikan juga dengan nasehatnasehatnya;

4) Suami mengikrarkan talak setelah disetujui oleh kedua belah pihak tentang besarnya iwadl, dan;

5) Jika tidak tercapai kesepakatan tentang Iwadl dari keduanya, maka pengadilan agama akan memutuskan perceraian sebagai perkara perceraian biasa. Jika hal tersebut terjadi, maka isteri dapat mengajukan hak nafkah kepada suami yang ingin dicerai gugatnya.

\section{Hak Nafkah Isteri Setelah Perceraian}

Peraturan Islam (fikih) menjelaskan bahwa jika seorang isteri meminta cerai (khulu') kepada suaminya, maka dia harus memberikan iwadl sesuai dengan yang diminta oleh suaminya, dengan kata lain suaminya sudah tidak lagi berkewajiban untuk menafkahi isteri yang menggugat cerainya. Namun di Indonesia negeri kita tercinta ini, memiliki hukum yang berlaku salah satunya tentang hak nafkah isteri setelah menggugat cerai suami, memang benar bahwa hukum Islam di Indonesia mengadopsi hukum fiqh Islam, namun yang 
membuatnya berbeda adalah hukum Islam di Indonesia terjadi sedikit perubahan yang menyebabkan timbulnya perbedaan antara cerai Khulu' dan cerai gugat. Bentuk perbedaanya terletak pada iwadl atau tebusan yang diberikan oleh isteri yang menggugat cerai suami, pada cerai khulu' terdapat penetapan iwadl yang akan diberikan isteri kepada suami, dan cerai gugat tidak ada ketentuan tersebut. Ketentuan ini dikarenakan setelah bercerai banyak akibat hukum yang akan mengikat dan memaksa kedua belah pihak, maka disarankan untuk menyertakan kuasa hukum jika penggugat atau tergugat masih kurang paham dan kurang pengalaman akan hukum.

Akibat hukum yang dijatuhkan kepada kedua belah pihak ditegaskan di dalam Undang-Undang Nomor 1 Tahun 1974 Tentang Perkawina (1974) pada pasal 41 di antaranya tentang pemeliharaan dan pendidikan anak, dan pemberian biaya untuk penghidupan bagi mantan isteri. Suami yang menjatuhkan talak kepada isterinya berkewajiban untuk memberikan mut'ah atau hadiah sebagai penghibur hati, memberikan nafkah pada saat masa iddah berupa pakaian dan tempat tinggal, nafkah untuk anak-anaknya sampai mereka mampu untuk menafkahi diri sendiri, dan melunaskan mas kawin apabila belum dilunasi.

Jika cerai talak jelas memberikan suami kewajiban memberikan nafkah setelah menikah, nafkah ini berupa mut'ah nafkah iddah dan nafkah mutihiyah, mut'ah sebaiknya berupa benda agat terpenuhi kemanfaatan dan memudahkan pada saat eksekusi, berbeda dengan cerai gugat atau permintaan cerai dari isteri maka pengadilan yang akan menentukan ketentuan terkait nafkah iddah yang diberikan sesuai dengan keadaan dari pasangan yang berperkara (Heniyatun et al., 2020).

Fikih Islam mengatur bahwa pemberian nafkah iddah disebabkan oleh jatuhnya talak kepada isteri yang dilakukan oleh suami, begitu pula yang disebutkan dalam KHI pasal 149 huruf b, pemberian nafkah iddah diberikan kecuali bekas isteri sudah dijatuhi talak ba'in atau berbuat nusyuz dan dalam keadaan tidak hamil. Namun demikian nafkah setelah perceraian disesuaikan dengan kemampuan suami. Jika yang menggugat cerai merupakan isteri yang ternyata korban kasus kekerasan dalam rumah tangga, dan memiliki keinginan untuk berpisah maka tugas hakim adalah mencermati pokok permasalahan yang sebenarnya terjadi, dan mengambil keputusan seadil-adilnya untuk kemaslahatan kedua pihak (Hikmatiar, 2018).

Terkait jika ada permintaan nafkah iddah untuk isteri yang merupakan korban kekerasan dalam rumah tangga dari suami yang digugat cerai, maka hakim harus benar-benar mencermati apakah isteri ini tidak melakukan nusyuz kepada suaminya atau benar-benar isteri tersebut merupakan korban kekerasan dalam 
rumah tangga. Dikarenakan isteri yang menggugat cerai juga berhak menuntut nafkah pasca perceraian. Maka dengan alasan adanya kekejaman dari suami yang dilakukan kepada korban selaku isterinya, maka hakim secara ex-officio dapat menetapkan nafkah iddah.

Jika pada cerai khulu' isteri harus membayar iwadl kepada suami, maka pada cerai talak isteri bisa mengajukan gugatan nafkah anak, nafkah isteri, mut'ah dan nafkah iddah pada saat bersamaan dengan pengajuan cerai gugat, hal ini terdapat pada Buku II pedoman pelaksanaan tugas dan Administrasi Peradilan agama yang dikeluarkan oleh Mahkamah Agung, hal ini menjadi tugas kepaniteraan untuk memberi tahu bahwa ada undang-undang yang menguntungkan Isteri dalam kasus cerai gugat, dikarenakan masih banyak orang yang awam terkait hal ini.

\section{KESIMPULAN}

Korban kekerasan dalam rumah tangga sering kali dialami oleh perempuan atau isteri, padahal Islam menyuruh suami untuk berbuat baik kepada isteri, namun jika hal ini terus terjadi, dan isteri menginginkan untuk berpisah dari suaminya, maka dia dapat melapor ke Pengadilan Agama untuk menggugat cerai suami yang melakukan kekerasan tersebut. Dalam kasus isteri sebagai korban kekerasan dalam rumah tangga dan tidak berbuat nusyuz kepada suami, dia dapat mengajukan gugatan hak nafkah anak, nafkah iddah dan mut'ah untuk selanjutnya dipertimbangkan oleh hakim untuk ditetapkan dengan seadil-adilnya.

\section{REFERENSI}

Anggraeni, R. D. (2013). Dampak kekerasan anak dalam rumah tangga. Universitas Jember.

Azizah, L. (2012). Analisis Perceraian dalam Kompilasi Hukum Islam. Al'Adalah, 10(2), 415-422.

Heniyatun, H., Anisah, S., \& others. (2020). Pemberian Mut'ah Dan Nafkah Iddah Dalam Perkara Cerai Gugat. Profetika: Jurnal Studi Islam, 21(1), 39-59.

Hikmatiar, E. (2018). Nafkah Iddah Pada Perkara Cerai Gugat. Mizan: Journal of Islamic Law, 4(1).

Kadarisman, A. (2017). Kekerasan Dalam Rumah Tangga dan Sanksinya dalam Hukum Islam. Journal de Jure, 9(2), 88-105.

Mardiyati, I. (2015). Dampak trauma kekerasan dalam rumah tangga terhadap perkembangan psikis anak. Jurnal Studi Gender Dan Anak, I (2), 26-29.

Rofiah, N. (2017). Kekerasan dalam rumah tangga dalam perspektif Islam. Wawasan: Jurnal Ilmiah Agama Dan Sosial Budaya, 2(1), 31-44. 
Al-Mujtahid: Journal of Islamic Family Law Vol. 1, No. 2 (2021): 105-112 Website: http://journal.iain-manado.ac.id/index.php/almujtahid

Undang-undang (UU) tentang Penghapusan Kekerasan dalam Rumah Tangga, (2004).

Undang-undang Nomor 1 Tahun 1974 tentang Perkawinan, (1974). 